\title{
CHARACTER EDUCATION AND MORAL VALUE IN 2D ANIMATION FILM ENTITLED "PENDETA BANGAU"
}

\author{
I Gede Adi Sudi Anggara ${ }^{1}$, Hendra Santosa ${ }^{2}$, dan A.A. Gde Bagus Udayana ${ }^{3}$ \\ ${ }_{1}^{1}$ Institut Seni Indonesia (ISI) Denpasar \\ 2 Institut Seni Indonesia (ISI) Denpasar \\ ${ }^{3}$ Institut Seni Indonesia (ISI) Denpasar \\ E-mail: hendrasnts@gmail.com
}

\begin{abstract}
Character is a very important and fundamental matter in a child's development. Character education has the same orientation with moral education, whereas moral education is very important in directing young generation to become good people through good values approach. In the midst of current IT advances, animated films are one of the effective and interesting media in transferring the values of character education and moral messages to children. The 2D animated film entitled Pendeta Bangau (The Priestess of Stork) is an animated film which source of story comes from Balinese folklore entitled Pedanda Baka. The aim of this study is to discuss the values of character education and moral messages/values contained in the animated film entitled "Pendeta Bangau". This study uses qualitative research methods with qualitative data analysis techniques model of Miles and Huberman. The result of this study shows that the character education values from the animated film entitled Pendeta Bangau contains the values of honesty, tolerate, friendship / communicative, love of peace, and curiosity. While the moral message/value was seen in the final/end of film, namely the Bangau (stork) died due to its immorality. Its Bangau dead is related to the principal of Prarabda Karmaphala, namely Bangau, gets the results of his behavior in the present, and is now available without being there anymore.
\end{abstract}

Keywords: Character building, morals, animated film, and Pendeta Bangau

\begin{abstract}
ABSTRAK
Karakter merupakan hal yang sangat penting dan mendasar dalam perkembangan anak. Pendidikan karakter memiliki orientasi yang sama dengan pendidikan moral, di mana pendidikan moral sangat penting dalam mengarahkan generasi muda menjadi manusia yang baik melalui pendekatan nilai-nilai kebaikan. Di tengah kemajuan TI saat ini, film animasi merupakan salah satu media yang efektif dan menarik dalam mentransfer nilai-nilai pendidikan karakter dan pesan moral kepada anak-anak. Film animasi 2D berjudul Pendeta Bangau merupakan film animasi yang sumber ceritanya berasal dari cerita rakyat Bali yang berjudul Pedanda Baka. Tujuan penelitian ini untuk membahas nilai-nilai pendidikan karakter dan moral yang terkandung dalam film animasi Pendeta Bangau. Penelitian ini menerapkan metode penelitian kualitatif dengan teknik analisis data kualitatif model Miles dan Huberman. Hasil penelitian ini menunjukkan bahwa nilai-nilai pendidikan karakter pada film animasi Pendeta Bangau meliputi nilai kejujuran, toleransi, bersahabat/komunikatif, cinta damai, dan rasa ingin tahu. Sedangkan pesan moralnya tampak di akhir film, yaitu Bangau mati akibat dari perbuatan tak bermoralnya. Hasil dari perilaku Bangau tersebut sesuai dengan ajaran hukum Prarabda Karmaphala, yaitu Bangau mendapatkan hasil dari perbuatannya pada masa kini, dan dinikmati saat ini juga tanpa ada sisanya lagi.
\end{abstract}




\section{CAPTURE}

Kata kunci: Pendidikan karakter, moral, film animasi, dan Pendeta Bangau

\section{PENDAHULUAN}

Pendidikan karakter merupakan hal yang sangat penting dalam perkembangan generasi penerus bangsa (Nuryantiningsih, 2017), karena bangsa yang kuat merupakan bangsa yang masyarakatnya memiliki karakter yang kuat dan berbudi pekerti yang baik dalam individual maupun sosial. Penguatan pendidikan karakter dalam konteks sekarang sangat relevan guna mengatasi krisis moral yang sedang terjadi di Indonesia.

Saat ini, di Bali sedang mengalami krisis moral yang nyata di masyarakat dengan melibatkan anak-anak sebagai pelakunya. Diantaranya, berita terkait kasus kriminalitas yang melibatkan anakanak dan remaja sebagai tersangka tindak kejahatan. Pada hari Kamis, 11 April 2019 BALIPOST.com 2019 memberitakan mengenai dua remaja berumur belasan tahun diamankan polisi karena mencuri emas dan uang di Kecamatan Susut, Bangli. Komisi Perlindungan Perempuan dan Anak Daerah (KPPAD) Bali dalam pemberitaan di BALIPOST.com 2017 menyatakan, berdasarkan pemantauan melalui media massa, kasus anak yang berhadapan dengan hukum, baik sebagai korban dan pelaku secara keseluruhan berjumlah 253 kasus. Ratusan kasus itu terdiri dari 137 kasus melibatkan anak sebagai pelaku tindak pidana. Kemudian, berdasarkan data yang diperoleh dari Direktorat Reserse Kriminal Umum Polda
Bali, menyebutkan bahwa pada triwulan I 2017 antara Januari hingga Maret 2017 terdapat 21 kasus tindak pidana kekerasan terhadap anak sebagai pelaku di Bali. Adapun kasus-kasus tersebut meliputi tindak pidana pencurian, persetubuhan, melarikan anak di bawah umur, kekerasan terhadap anak, pengrusakan, curat serta perbuatan tidak menyenangkan.

Tabel 1. Data kasus tindak pidana kekerasan terhadap anak sebagai pelaku (Januari - Maret 2017)

(Sumber: Dir.Reserse Kriminal Umum Polda Bali)

\begin{tabular}{|c|l|c|}
\hline No. & \multicolumn{1}{|c|}{ Tindak Pidana } & Jumlah \\
\hline 1. & Pencurian & 10 \\
\hline 2. & Persetubuhan & 3 \\
\hline 3. & $\begin{array}{l}\text { Melarikan anak di bawah } \\
\text { umur }\end{array}$ & 1 \\
\hline 4. & Kekerasan terhadap anak & 2 \\
\hline 5. & Pengrusakan & 1 \\
\hline 6. & $\begin{array}{l}\text { Curat (pencurian dengan } \\
\text { pemberatan) }\end{array}$ & 1 \\
\hline 7. & $\begin{array}{l}\text { Perbuatan tidak } \\
\text { menyenangkan }\end{array}$ & 3 \\
\hline
\end{tabular}

Berdasarkan hasil wawancara dengan budayawan dan maestro seni tradisi lisan, Made Taro, menyatakan bahwa tindak pidana anak sebagai pelaku terjadi dikarenakan kurangnya pendidikan karakter yang ditanamkan kepada anakanak sejak usia dini. Di mana penguatan pendidikan karakter salah satunya dapat disampaikan melalui pesan-pesan moral dan nilai-nilai pendidikan yang terkandung dalam cerita rakyat. Nilai-nilai pendidikan karakter dan pesan moral terdapat dalam salah satu cerita rakyat Bali, yaitu cerita 
Vol.10 No.2 Juli 2019

Pedanda Baka.

Cerita rakyat merupakan seni tradisi lisan yang melekat erat pada suatu daerah tertentu dan diturunkan dari generasi ke generasi dalam berbagai versi. Cerita rakyat pada awalnya disampaikan dari mulut ke mulut melalui kegiatan mendongeng. Menurut Danandjaja (1991), istilah cerita rakyat menunjuk kepada cerita yang merupakan bagian dan rakyat, yaitu hasil sastra yang termasuk ke dalam cakupan folklor. Kata 'folklor' adalah pengindonesiaan kata Inggris folklore. Kata itu adalah kata majemuk, yang berasal dan dua kata dasar folk dan lore. Namun, dalam perkembangannya, cerita rakyat tak hanya disampaikan melalui lisan atau buku cerita saja tetapi jugadapat disampaikan melalui teknologi digital, menyesuaikan dengan era teknologi sekarang ini, seperti cerita rakyat Bali, Pedanda Baka, yang telah dirancang menjadi sebuah film animasi 2D dengan judul Pendeta Bangau.

Film animasi 2D Pendeta Bangau tidak merubah esensi dari cerita Pedanda Baka. Cerita ini mengisahkan seekor Bangau yang berpura-pura menjadi pendeta yang baik hati dan menipu para penghuni telaga Kumudasara. Pendeta Bangau dengan licik dan penuh tipu daya membohongi ikan-ikan penghuni telaga bahwa air telaga akan dikeringkan oleh para petani. Burung Bangau tersebut berjanji akan memindahkan mereka ke telaga Andawana yang konon airnya lebih jernih. Ikan-ikan yang dilanda ketakutan tersebut menyerahkan seluruh nasibnya kepada Pendeta Bangau. Mereka percaya dan bersedia dipindahkan, namun pada akhirnya satu per satu ikan-ikan tersebut dibunuh dan dimangsa di atas sebuah bukit. Seluruh ikan-ikan di telaga Kumudasara habis dimakan Bangau dan yang tersisa hanyalah si kepiting. Si Kepiting pun meminta agar ikut serta dipindahkan ke telaga Andawana yang diceritakan oleh sang Pendeta Bangau. Bangau yang serakah dan licik itu pun bersedia membawa si Kepiting, dan berencana untuk memakannya juga. Di perjalanan Kepiting melihat tulang-tulang ikan yang merupakan teman-temannya berserakan di atas sebuah bukit. Seketika itu pula si Kepiting sadar akan perbuatan jahat si Pendeta palsu itu. Kepiting yang marah kemudian mencekik leher Bangau tersebut hingga patah dan akhirnya mati.

Cerita Pedanda Baka tersebut sarat akan nilai-nilai pendidikan karakter melalui pesan-pesan moralnya. Cerita tersebut disajikan dalam sebuah film animasi 2D berjudul Pendeta Bangau. Menurut Trianton (2013), film merupakan karya sinematografi yang dapat berfungsi sebagai alat pendidikan budaya dan efektif untuk menyampaikan nilai-nilai budaya. Dalam hasil wawancara dengan Made Taro, dinyatakan cerita rakyat merupakan salah satu warisan budaya bangsa yang sarat akan pesan moral yang berguna bagi 


\section{CAPTURE}

pendidikan karakter anak sejak usia dini. Hal senada juga diungkapkan oleh (Parmini 2015), pembentukan karakter ini bisa dilakukan antara lain dengan mengajak anak-anak usia sekolah dasar menyimak kisah-kisah atau cerita rakyat yang menjadi khasanah kearifan lokal.

Tujuan dari penelitian ini adalah untuk mengungkapkan nilai-nilai pendidikan karakter yang ada dalam film animasi Pendeta Bangau, sehingga dapat dikonstruksikan dengan mudah oleh masyarakat secara luas. Selain itu, dapat menjadi salah satu referensi film animasi 2D dengan bertemakan cerita rakyat yang sarat akan nilai-nilai pendidikan karakter.

Penelitian ini hanya menganalisis isi dari tayangan film animasi Pendeta Bangau. Penelitian ini tidak membahas masalah-masalah yang menyangkut teknis pembuatan film animasi. Penelitian ini dibatasi pada tayangan-tayangan yang dianggap sebagai bentuk dari pesan-pesan yang mencerminkan tentang nilai-nilai pendidikan karakter.

\section{TINJAUAN TEORI}

a. Teori Belajar Konstruktivisme

Teori belajar konstruktivisme dipelopori oleh Piaget, Bruner dan Vygotsky yang mempunyai pandangan bahwa pengetahuan dan pemahaman tidaklah diperoleh secara pasif akan tetapi dengan cara yang aktif melalui pengalaman personal dan aktivitas eksperiental. Selain itu Cooper menjelaskan bahwa konstruktivisme memandang peserta didik menginterpretasi informasi sesuai dengan realitas personal mereka, dan mereka belajar melalui observasi, proses dan interpretasi dan membentuk informasi tersebut ke dalam pengetahuan personalnya (Rusman, 2017).

Teori belajar konstruktivisme digunakan untuk mengungkapkan nilai-nilai pendidikan karakter yang ada dalam film animasi Pendeta Bangau. Informasi mengenai cerita dan nilai-nilai pendidikan karakter dan pesan moral yang ada pada film animasi Pendeta Bangau tidak diperoleh secara pasif oleh audiens (dalam hal ini merupakan peneliti), melainkan melalui cara yang aktif yaitu dengan cara menontonnya. Setelah menonton film animasi 2D ini hingga usai, peneliti kemudian dapat menginterpretasi informasi mengenai nilai-nilai pendidikan karakter yang ada pada film animasi Pendeta Bangau.

\section{b. Analisis Data Interactive Model}

Analisis data dalam penelitian kualitatif, dilakukan pada saat pengumpulan data berlangsung, dan setelah selesai pengumpulan data dalam periode tertentu. Miles dan Huberman (1984), mengemukakan bahwa aktivitas dalam analisis data kualitatif dilakukan secara interaktif dan berlangsung secara terus menerus sampai tuntas, sehingga datanya sudah jenuh (Sugiyono, 2015).

Menurut Sugiyono (2015) terdapat 
tiga komponen dalam metode analisis data model Miles dan Huberman. Pertama reduksi data (data reduction), dimana data yang diperoleh dicatat dan dirinci kemudian dirangkum dan dipilih hal-hal yang pokok, memfokuskan pada hal-hal yang penting. Kedua, penyajian data (data display) dimana setelah mereduksi data, dilakukan penyajian data. Penyajian data dalam penelitian kualitatif ini dapat dilakukan dalam bentuk uraian singkat, bagan, flowchart, dan sejenisnya. Ketiga, adalah penarikan kesimpulan (conclusion drawing), kesimpulan dalam penelitian kualitatif mungkin dapat menjawab rumusan masalah, mungkin juga tidak, karena masalah dan rumusan masalah dalam penelitian kualitatif masih bersifat sementara dan akan berkembang setelah penelitian berada di lapangan.

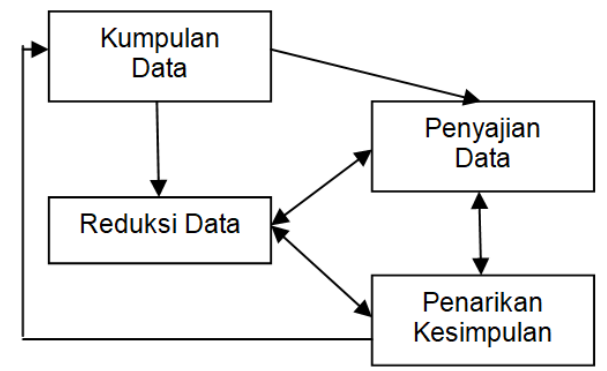

Gambar 1. Komponen dalam analisis data model Miles dan Huberman (Interactive Model)

\section{c. Pendidikan Karakter}

Menurut David \& Freddy pendidikan karakter adalah usaha sengaja (sadar) untuk membantu manusia memahami, peduli tentang, dan melaksanakan nilai-nilai etika inti. Williams \& Schnaps juga mendefinisikan pendidikan karakter sebagai usaha yang dilakukan oleh para personel sekolah, bahkan yang dilakukan bersama-sama dengan orang tua dan anggota masyarakat, untuk membantu anak-anak dan remaja agar menjadi atau memiliki sifat peduli, berpendirian, dan bertanggung jawab (Zubaedi, 2011).

Nilai-nilai yang dikembangkan dalam pendidikan karakter di Indonesia diidentifikasi berasal dari empat sumber, yakni 1) agama, 2) Pancasila, 3) budaya dan 4) tujuan pendidikan nasional. Berdasarkan keempat sumber nilai tersebut, teridentifikasi sejumlah nilai untuk pendidikan karakter (Zubaedi, 2011).

Tabel 2. Nilai dan deskripsi nilai pendidikan karakter

\begin{tabular}{|c|c|c|}
\hline No & $\begin{array}{c}\text { Nilai } \\
\text { Pendidikan } \\
\text { Karakter }\end{array}$ & Deskripsi \\
\hline 1. & Religius & $\begin{array}{l}\text { Sikap dan perilaku yang } \\
\text { patuh dalam melak- } \\
\text { sanakan ajaran agama } \\
\text { yang dianutnya dan } \\
\text { hidup rukun dengan } \\
\text { pemeluk agama lain. }\end{array}$ \\
\hline 2. & Jujur & $\begin{array}{l}\text { Perilaku yang didasarkan } \\
\text { pada upaya menjadikan } \\
\text { dirinya sendirisebagai } \\
\text { orang yang selalu dapat } \\
\text { dipercaya dalam perkata- } \\
\text { an, tindakan dan } \\
\text { pekerjaan. }\end{array}$ \\
\hline 3. & Toleransi & $\begin{array}{l}\text { Sikap dan tindakan yang } \\
\text { menghargai perbedaan. }\end{array}$ \\
\hline 4. & Disiplin & $\begin{array}{l}\text { Tindakan yang menun- } \\
\text { jukkan perilaku tertib dan } \\
\text { patuh pada peraturan. }\end{array}$ \\
\hline 5. & Kerja Keras & $\begin{array}{l}\text { Perilaku yang menunjuk- } \\
\text { kan upaya sungguh- } \\
\text { sungguh dalam menye- } \\
\text { lesaikan tugas dengan } \\
\text { sebaik-baiknya. }\end{array}$ \\
\hline 6. & Kreatif & $\begin{array}{l}\text { Berpikir dan melakukan } \\
\text { sesuatu untuk meng- } \\
\text { hasilkan cara atau hasil } \\
\text { baru dari sesuatu yang } \\
\text { telah ada. }\end{array}$ \\
\hline 7. & Mandiri & Sikap dan perilaku yang \\
\hline
\end{tabular}




\section{CAPTURE}

\begin{tabular}{|c|c|c|}
\hline & & $\begin{array}{l}\text { tidak mudah tergantung } \\
\text { pada orang lain. }\end{array}$ \\
\hline 8. & Demokratis & $\begin{array}{l}\text { Cara berpikir, bersikap, } \\
\text { dan bertindak yang } \\
\text { menilai sama hak dan } \\
\text { kewajiban dirinya dan } \\
\text { orang lain. }\end{array}$ \\
\hline 9. & $\begin{array}{l}\text { Rasa Ingin } \\
\text { Tahu }\end{array}$ & $\begin{array}{l}\text { Sikap yang selalu } \\
\text { berupaya untuk me- } \\
\text { ngetahui lebih dalam dari } \\
\text { sesuatu yang dipelajari, } \\
\text { dilihat dan didengar. }\end{array}$ \\
\hline 10 & $\begin{array}{l}\text { Semangat } \\
\text { Kebangsaa } \\
n\end{array}$ & $\begin{array}{l}\text { Cara berpikir, bertindak } \\
\text { dan berwawasan yang } \\
\text { menempatkan } \\
\text { kepentingan bangsa dan } \\
\text { negara diatas kepen- } \\
\text { tingan diri dan kelompok. }\end{array}$ \\
\hline 11 & $\begin{array}{l}\text { Cinta } \\
\text { Tanah Air }\end{array}$ & $\begin{array}{l}\text { Cara berpikir dan } \\
\text { berbuat yang menunjuk- } \\
\text { kan kesetiaan, kepe- } \\
\text { dulian dan penghargaan } \\
\text { yang tinggi terhadap } \\
\text { bangsa dan tanah air. }\end{array}$ \\
\hline 12 & $\begin{array}{l}\text { Menghargai } \\
\text { Prestasi }\end{array}$ & $\begin{array}{l}\text { Sikap dan tindakan yang } \\
\text { mengakui serta meng- } \\
\text { hormati keberhasilan diri } \\
\text { sendiri dan orang lain. }\end{array}$ \\
\hline 13 & $\begin{array}{l}\text { Bersahabat } \\
\text { /Komunikati } \\
\text { f }\end{array}$ & $\begin{array}{l}\text { Tindakan yang memper- } \\
\text { lihatkan rasa senang } \\
\text { berbicara, bergaul, dan } \\
\text { bekerja sama dengan } \\
\text { orang lain. }\end{array}$ \\
\hline 14 & $\begin{array}{l}\text { Cinta } \\
\text { Damai }\end{array}$ & $\begin{array}{l}\text { Sikap, perkataan, dan } \\
\text { tindakan yang menye- } \\
\text { babkan orang lain } \\
\text { merasa senang dan } \\
\text { aman atas kehadiran } \\
\text { dirinya. }\end{array}$ \\
\hline 15 & $\begin{array}{l}\text { Gemar } \\
\text { Membaca }\end{array}$ & $\begin{array}{l}\text { Kebiasaan menyediakan } \\
\text { waktu untuk membaca } \\
\text { berbagai bacaan. }\end{array}$ \\
\hline 16 & $\begin{array}{l}\text { Peduli } \\
\text { Lingkungan }\end{array}$ & $\begin{array}{l}\text { Sikap dan tindakan yang } \\
\text { berupaya mencegah ke- } \\
\text { rusakan lingkungan } \\
\text { sekitar dan memperbaiki } \\
\text { kerusakan lingkungan } \\
\text { yang sudah terjadi. }\end{array}$ \\
\hline 17 & $\begin{array}{l}\text { Peduli } \\
\text { Sosial }\end{array}$ & $\begin{array}{l}\text { Sikap dan tindakan yang } \\
\text { selalu ingin memberi } \\
\text { bantuan pada orang lain } \\
\text { yang membutuhkan. }\end{array}$ \\
\hline 18 & $\begin{array}{l}\text { Tanggung } \\
\text { Jawab }\end{array}$ & $\begin{array}{l}\text { Sikap dan perilaku } \\
\text { seseorang untuk melak- } \\
\text { sanakan tugas dan } \\
\text { kewajibannya. }\end{array}$ \\
\hline
\end{tabular}

d. Nilai Moral
Pendidikan karakter memiliki kesamaan orientasi dengan pendidikan moral. Hal ini dikarenakan pendidikan moral merupakan sebuah komitmen tentang langkah-langkah apa yang seharusnya dilakukan oleh seorang pendidik untuk mengarahkan generasi muda pada nilai-nilai kebajikan yang akan membentuknya menjadi manusia yang baik. Brendt (dalam Zubaedi, 2011), mengemukakan bahwa moral adalah prinsip untuk menentukan perilaku. Prinsip ini berkaitan dengan sangsi atau hukum yang diberlakukan pada setiap individu. Kriteria menentukan seseorang bermoral atau tidak adalah norma. Ada beberapa norma yang berlaku dalam kehidupan masyarakat, salah satunya adalah norma agama.

Salah satu norma agama Hindu di Bali yang berlaku dalam masyarakat adalah hukum Karmaphala. Wiguna (2015) menyatakan cerita rakyat atau lebih dikenal dengan satua di Bali sebagian besar merupakan kisah tentang hukum karmaphala. Kata Karmaphala berasal dari bahasa Sansekerta yakni karma yang berarti perbuatan dan phala yang berarti hasil, sehingga hukum karmaphala merupakan hukuman yang dihasilkan dari perbuatan seseorang.

\section{e. Film Animasi Pendeta Bangau}

Film adalah hasil proses kreatif para sineas yang memadukan berbagai unsur seperti gagasan, sistem nilai, 
pandangan hidup, keindahan, norma, tingkah laku manusia, dan kecanggihan teknologi. Meski berupa tontonan, namun film memiliki pengaruh yang besar dalam fungsi pendidikan, hiburan, informasi dan pendorong tumbuhnya industry kreatif (Trianton, 2013), sedangkan menurut (Zaharuddin G., 2006) film adalah gambar hidup atau rangkaian gambar-gambar yang bergerak menjadi suatu alur cerita yang ditonton orang. Apresiasi atau penilaian terhadap film berarti menilai sebuah film berdasarkan kriteria tertentu. Penilaian ini lebih dikenal dengan resensi film. Resensi film adalah sebuah karya tulis yang isinya memberi pertimbangan tentang baik dan buruknya kualitas sebuah film (Iskak, 2006). Menurut (Pratista, 2008) film secara umum dapat dibagi atas dua unsur pembentuk yakni, unsur naratif dan unsur sinematik. Dua unsur tersebut saling berinteraksi dan berkesinambungan satu sama lain untuk membentuk sebuah film. Masing-masing unsur tersebut tidak akan dapat membentuk film jika hanya berdiri sendiri, bisa dikatakan bahwa unsur naratif adalah bahan (materi) yang akan diolah, sementara unsur sinematik adalah cara (gaya) untuk mengolahnya.

Animasi berasal dari bahasa latin, 'anima' yang berarti jiwa, hidup, nyawa, dan semangat. Animasi adalah film yang berasal dari gambar-gambar yang diolah sedemikian rupa hingga menjadi sebuah gambar bergerak dan bercerita (Gunawan,
2013). Menurut Bustaman (2001) animasi adalah suatu proses dalam menciptakan efek gerakan atau perubahan dalam jangka waktu tertentu, dapat juga berupa perubahan warna dari suatu objek dalan jangka waktu tertentu dan bisa juga dikatakan berupa perubahan bentuk dari suatu objek ke objek lainnya dalam jangka waktu tertentu. Sedangkan menurut Prakosa (2010), animasi secara luas berbicara masalah bentuk suatu benda yang berubah-ubah menciptakan gerak dan kehidupan. Zembry (2001) berpendapat animasi adalah pembuatan gambar atau isi yang berbeda-beda pada setiap frame, kemudian dijalankan rangkaian frame tersebut menjadi sebuah motion atau gerakan sehingga terlihat seperti sebuah film.

Film animasi Pendeta Bangau merupakan film animasi 2D fiksi, dimana tokoh, peristiwa, ruang dan waktunya direkayasa (tidak benar terjadi). Karakter dalam film animasi 2D ini merupakan karakter karakter animasi dengan style fabel. Karakter animasi style fabel merupakan karakter akan mempersonifikasikan bentuk binatang, dengan sifat-sifat yang mendekati jenis binatangnya (Gunawan, 2013). Struktur yang membangun film animasi Pendeta Bangau ini terdiri dari 3 unsur yaitu shot, scene dan sequence, serta menggunakan urutan waktu berpola linier. Pola Linier yaitu waktu berjalan sesuai urutan aksi 


\section{CAPTURE}

peristiwa tanpa adanya interupsi waktu yang signifikan. Penuturan cerita secara linier memudahkan audiens untuk melihat hubungan kausalitas jalinan satu peristiwa dengan peristiwa lainnya pada film animasi ini (Pratista, 2008).

\section{METODE}

Penelitian ini menerapkan metode penelitian kualitatif dengan menganalisa isi media. Metode penelitian kualitatif sering disebut metode penelitian naturalistik karena penelitiannya dilakukan pada kondisi yang alamiah (natural setting); disebut sebagai metode kualitatif, karena data yang terkumpul dan analisisnya lebih bersifat kualitatif (Sugiyono, 2015).

Teknik pengumpulan data yang digunakan adalah pertama, wawancara dengan Made Taro selaku budayawan dan mastero seni tradisi lisan. Kedua, dokumentasi berupa file film animasi Pendeta Bangau dengan format .Mp4, scene yang dianggap memuat nilai-nilai pendidikan karakter. Ketiga, studi kepustakaan dari beberapa buku dan artikel terkait penelitian. Data yang diperoleh dari wawancara dan dokumentasi merupakan data primer, sedangkan studi kepustakaan merupakan data sekunder.

Pada penelitian ini, teknik analisis data yang digunakan adalah teknik analisis data kualitatif model Miles dan Huberman. Teknik analisis data ini digunakan peneliti dengan tujuan untuk menemukan, mengumpulkan, mengidentifikasi, mengo- lah dan menganalisis keseluruhan scene dalam film animasi Pendeta Bangau. Kemudian, mengetahui, memahami dan dapat menyajikan nilai-nilai pendidikan karakter yang disampaikan pada film animasi Pendeta Bangau.

Dalam penerapannya, setiap pesan yang mengandung nilai-nilai pendidikan karakter dalam film animasi Pendeta Bangau dimasukkan ke dalam kategori nilai-nilai pendidikan karakter yang telah direduksi sebelumnya. Kemudian, data tersebut dianalisis untuk memperoleh dan menentukan nilai-nilai pendidikan karakter yang telah dikategorikan. Selanjutnya, data tersebut kemudian disajikan (data display), yang dalam penelitian ini penyajian data dilakukan dalam bentuk uraian singkat dengan teks yang bersifat naratif. Kemudian, dilakukan penarikan kesimpulan (conclusion drawing) dari hasil analisis yang telah disajikan untuk menjawab rumusan masalah, yaitu nilia-nilai pendidikan karakter pada film animasi Pendeta Bangau.

Penelitian ini berfokus pada meneliti karakter dan keseluruhan scene yang terdapat pada film animasi Pendeta Bangau, yang berkaitan dengan penyampaian pesan-pesan yang mencerminkan nilai-nilai pendidikan karakter dan pesan moral. Peneliti menganalisis pesan moral yang dalam film animasi Pendeta Bangau dengan mengkategorikan nilai-nilai pendidikan 
karakter dengan melakukan reduksi data dari data yang telah dikumpulkan, yaitu:

a. Jujur, perilaku yang didasarkan pada upaya menjadikan dirinya sendiri sebagai orang yang selalu dapat dipercaya dalam perkataan, tindakan dan pekerjaan.

b. Toleransi, sikap dan tindakan yang menghargai perbedaan.

c. Bersahabat/Komunikatif, tindakan yang memperlihatkan rasa senang berbicara, bergaul, dan bekerja sama dengan orang lain.

d. Cinta Damai, merupakan sikap, perkataan, dan tindakan yang menyebabkan orang lain merasa senang dan aman atas kehadiran dirinya.

e. Rasa Ingin Tahu, sikap yang selalu berupaya untuk mengetahui lebih dalam dari sesuatu yang dipelajari, dilihat dan didengar.

Analisis pesan moral dalam penelitian ini, peneliti berpedoman pada salah norma agama Hindu, yaitu hukum Karmaphala. Menurut Netra (2009) hukum Karmaphala dibagi menjadi tiga yaitu:

a. Sancita Karmaphala, hasil perbuatan yang tidak habis dinikmati di kehidupan terdahulu, dan dinikmati di kehidupan sekarang

b. Prarabda Karmaphala, hasil dari perbuatan pada masa kini, tanpa ada sisanya lagi. c. Kryamana Karmaphala, hasil perbuatan yang tidak sempat dinikmati sehingga harus dinikmati pada kehidupan selanjutnya.

Uji keabsahan data dalam penelitian kualitatif meliputi uji kredibilitas, pengujian transferability, pengujian depenability, dan uji konfirmability (Sugiyono, 2015). Peneliti menggunakan uji kredibilitas dan reliabilitas (depenability) untuk pengujian keabsahan data dalam penelitian ini. Uji kredibilitas dalam penelitian ini dilakukan dengan cara diskusi dengan teman sejawat dan mengingkatkan ketekunan. Kemudian, untuk menghasilkan penelitian yang reliabel peneliti melakukan uji reliabilitas (depenability), dengan cara melakukan audit terhadap keseluruhan proses penelitian. Audit keseluruhan aktivitas peneliti mulai menentukan masalah, memasuki lapangan, menentukan sumber data, menganalisis data, pengujian sampai penarikan kesimpulan terhadap nilai-nilai pendidikan karakter yang terkandung dalam film animasi Pendeta Bangau.

\section{PEMBAHASAN}

Setelah menganalisis data dengan teknik analisis data model Miles dan Huberman serta uji kredibilitas dengan meningkatkan ketekunan dan diskusi dengan teman sejawat dilakukan, peneliti melakukan penyempurnaan dan keabsahan data dengan uji reliabilitas (dependability). Selanjutnya, peneliti dapat 


\section{CAPTURE}

menyajikan ulasan dari hasil penelitian berupa nilai pendidikan karakter dan nilai moral yang terkandung di dalam film animasi tersebut.

\subsection{Nilai Pendidikan Karakter dalam Film Animasi Pendeta Bangau}

Berikut ini nilai-nilai pendidikan karakter dalam film animasi Pendeta

\section{Bangau:}

1. Nilai Pendidikan Karakter "Jujur" dalam

Film Animasi Pendeta Bangau

Scene ke-5 dalam film animasi

Pendeta Bangau memperlihatkan para ikan-ikan penghuni Telaga Kumudasara dengan jujur mengatakan pada Bangau bahwa mereka sangat ketakutan jika Telaga Kumudasara akan dikeringkan oleh para petani. Mereka juga berkata secara jujur bahwa percaya dengan kata-kata sang Bangau dan berserah diri jika harus dipindahkan ke Telaga Andawana oleh Bangau yang berpura-pura menjadi pendeta tersebut. Sebaliknya, sikap tidak jujur ditunjukkan oleh karakter Pendeta Bangau yang berbohong kepada para penghuni Telaga Kumudasara.

Nilai pendidikan karakter jujur juga ditunjukkan oleh karakter Kepiting. Scene ke-9 memperlihatkan adegan Kepiting secara jujur mengakui dirinya ingin dibawa ke Telaga Andawana meski akan menjadi beban Bangau karena bentuk tubuhnya yang besar, keras dan berat. Kepiting juga berkata secara jujur kepada Bangau bahwa dirinya tak akan bisa hidup sendiri, jika
Telaga Kumudasara tak dihuni lagi oleh para sahabatnya, para ikan.

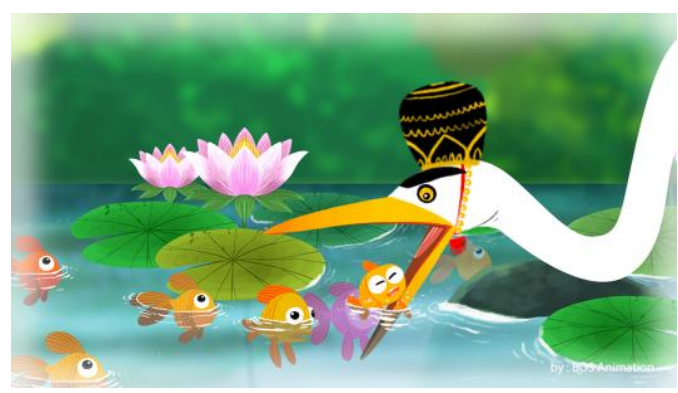

Gambar 2. Saat ikan-ikan menyerahkan diri kepada Bangau untuk dipindahkan

(Sumber: Cuplikan layar film animasi Pendeta Bangau, TC:06:30")

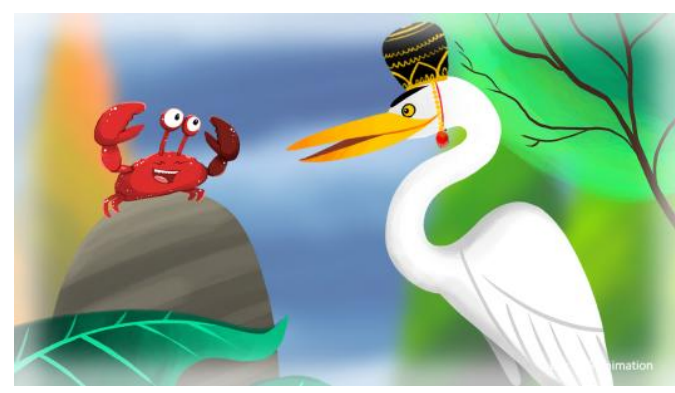

Gambar 3. Saat Kepiting ingin dipindahkan juga ke Telaga Andawana

(Sumber: Cuplikan layar film animasi Pendeta Bangau, TC: 09:10")

2. Nilai Pendidikan Karakter "Toleransi" dalam Film Animasi Pendeta Bangau

Scene ke-2 dalam film animasi Pendeta Bangau menggambarkan sikap toleransi para ikan-ikan penghuni Telaga Kumudasara.

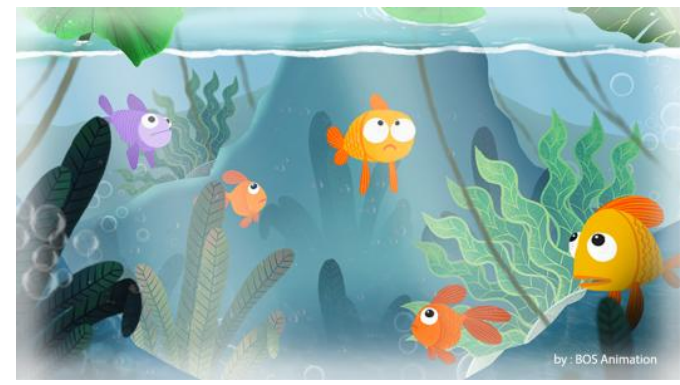

Gambar 4. Ikan-ikan hidup dengan toleransi antara satu dengan lainnya

(Sumber: Cuplikan layar film animasi Pendeta Bangau, TC: 00:30") 
Meski berbeda jenis, warna dan ukuran antara satu dan yang lainnya, para ikan-ikan tersebut tetap menghargai perbedaan yang ada. Mereka hidup dengan rukun dan berbahagia dalam satu habitat, yaitu Telaga Kumudasara, sehingga dengan sikap toleransi, kerukunan dapat tercipta meski dengan perbedaan yang ada.

\section{Nilai Pendidikan Karakter "Bersahabat/}

Komunikatif" dalam Film Animasi

\section{Pendeta Bangau}

Sikap bersahabat dan komunikatif pada film animasi Pendeta Bangau terlihat pada scene ke-3. Para penghuni Telaga Kumudasara yaitu para ikan sangat bersahabat dan komunikatif dengan Bangau, meski Bangau merupakan mahkluk lain yang bukan dari kelompok para ikan. Para ikan bersedia dengan senang hati berbicara, berdiskusi dan mendengarkan ceramah dari Pendeta Bangau, meskipun tahu bahwa Bangau tersebut merupakan pemangsa mereka.

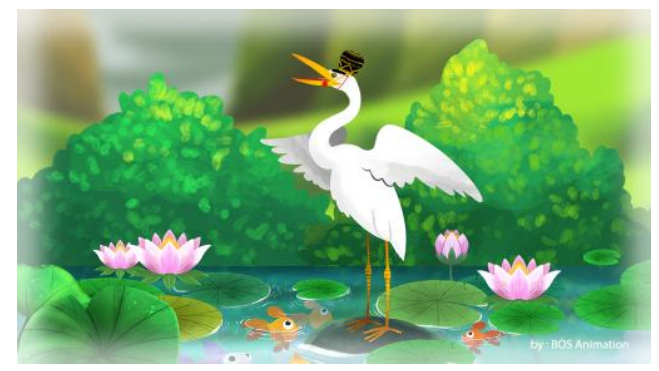

Gambar 5. Ikan-ikan hidup dengan sikap bersahabat dan komunikatif mendengarkan ceramah Bangau (Sumber: Cuplikan layar film animasi Pendeta Bangau, TC: 03:30")
4. Nilai Pendidikan Karakter "Cinta Damai" dalam Film Animasi Pendeta Bangau

Sikap cinta damai pada film animasi Pendeta Bangau ditunjukkan pada scene ke-3, di mana Bangau menunjukkan sikap, perkataan, dan tindakan yang menyebabkan para ikan penghuni Telaga Kumudasara merasa senang dan aman atas kehadiran dirinya. Di samping itu, Bangau menahan diri untuk tidak memangsa para ikan dengan tujuan mendapatkan simpati dan perhatian dari mereka para ikan penghuni Telaga.

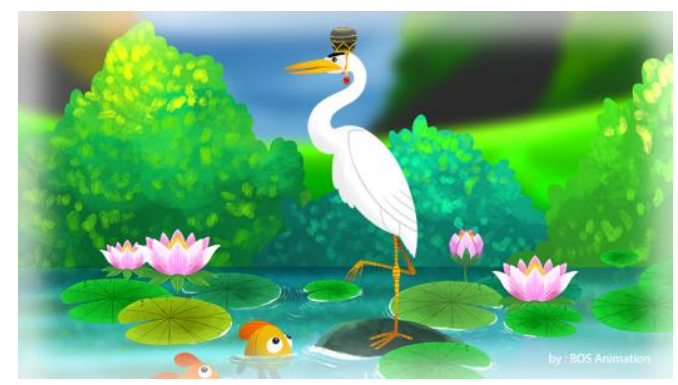

Gambar 6. Bangau hadir di Telaga Kumudasara dengan cinta damai demi mendapatkan simpati ikan.

(Sumber: Cuplikan layar film animasi Pendeta Bangau, TC: 02:30")

Selain Bangau, sikap cinta damai juga ditunjukkan oleh para ikan, mereka menerima Bangau hadir di dekat mereka, meskipun tahu bahwa biasanya Bangau merupakan pemangsa para ikan.

\section{Nilai Pendidikan Karakter "Rasa Ingin \\ Tahu" dalam Film Animasi Pendeta \\ Bangau \\ Sikap rasa ingin tahu pada film} animasi ini ditunjukkan pada scene ke-4. Kepiting mengintip dari celah-celah rerumputan dan bebatuan karena 


\section{CAPTURE}

penasaran dan ingin mengetahui tentang apa yang sedang dibicarakan Bangau kepada para ikan. Keingintahuan Kepiting ini sangat beralasan, karena Kepiting sedari awal tahu rencana jahat sang Bangau yang berpura-pura menjadi pendeta demi menarik perhatian para ikan. Namun, keraguan dalam hati Kepiting mendorong rasa ingin tahu tentang apa yang sebenarnya yang direncanakan oleh Bangau.

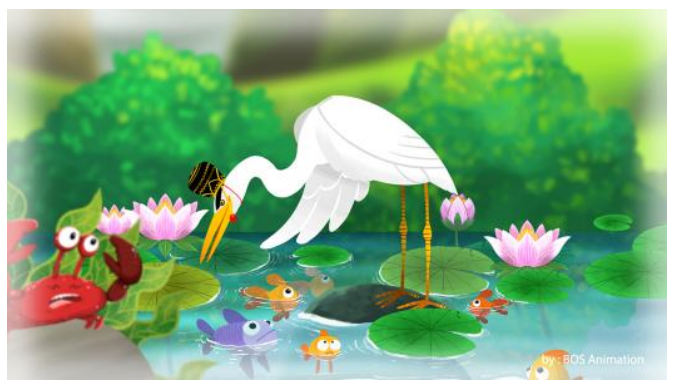

Gambar 7. Kepiting mengintip, ingin tahu apa yang dibicarakan Bangau dan ikan-ikan

(Sumber: Cuplikan layar film animasi Pendeta Bangau, TC: 05:10")

\subsection{Pesan Moral dalam Film Animasi Pendeta Bangau}

Adegan dalam film animasi Pendeta Bangau menggambarkan Bangau mati di akhir cerita akibat segala perbuatan buruknya. Bangau yang licik, tidak jujur, serakah, menipu para penghuni Telaga Kumudasara demi keuntungan dirinya mendapatkan hukuman yang setimpal. Berpura-pura menjadi pendeta dan berbuat yang tidak sesuai moral pada akhirnya mati tercekik oleh Kepiting yang merupakan karakter protagonis dalam film animasi ini. Bangau mendapatkan hasil dari perbuatannya, yaitu berbohong dan serakah serta memanfaatkan orang lain demi kepentingan diri sendiri. Hasil dari perbuatan Bangau tersebut sesuai dengan ajaran hukum Prarabda Karmaphala, yaitu Bangau mendapatkan hasil dari perbuatan pada masa kini, dan dinikmati saat ini juga tanpa ada sisanya lagi.

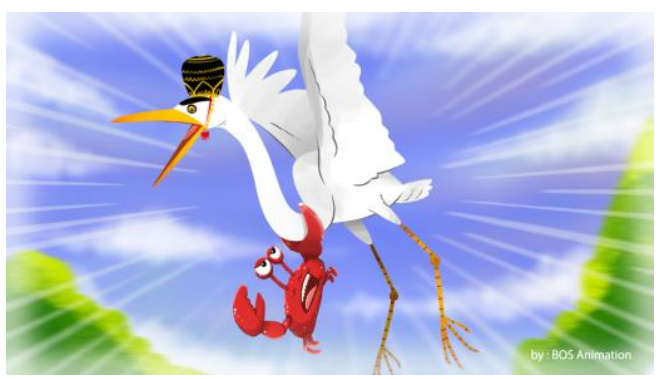

Gambar 8. Kepiting mencekik leher Bangau saat mengetahui bahwa kebohongan Bangau (Sumber: Cuplikan layar film animasi Pendeta Bangau, TC: 11:25")

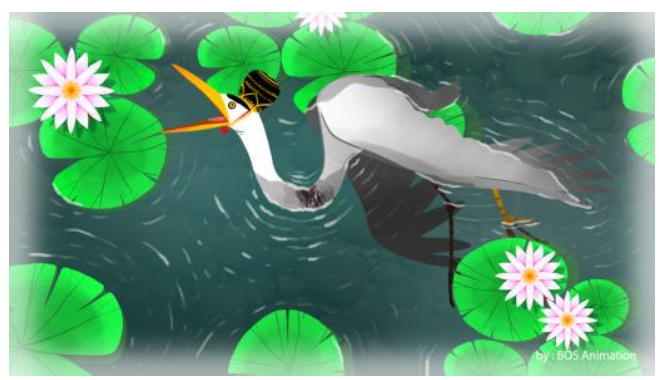

Gambar 8. Bangau mati tercekik oleh Kepiting, karena perbuatan tak bermoralnya.

(Sumber: Cuplikan layar film animasi Pendeta Bangau, TC: 14:45")

Berdasarkan hasil wawancara dengan Made Taro, cerita rakyat Pedanda Baka ini mengandung pesan-pesan moral seperti tidak boleh membohongi dan menipu orang lain demi keuntungan pribadi, sebaliknya kita harus jujur dan menjunjung tinggi nilai kebenaran, serta jangan mudah percaya kepada orang lain dengan hanya melihat dari penampilan luarnya saja. Siapapun yang melakukan 
Vol.10 No.2 Juli 2019

perbuatan tidak baik dan tidak bermoral akan mendapatkan hukuman yang setimpal sesuai ajaran norma agama Hindu, salah satunya hukum Karmaphala.

\section{SIMPULAN}

Dari penelitian ini diperoleh hasil bahwa, film animasi 2D Pendeta Bangau mengandung nilai-nilai pendidikan karakter diantaranya, jujur, toleransi, bersahabat/ komunikatif, cinta damai dan rasa ingin tahu. Selain itu, film animasi ini juga sarat dengan pesan-pesan moral diantaranya, tidak boleh membohongi dan menipu orang lain demi keuntungan pribadi namun sebaliknya kita harus jujur dan menjunjung tinggi nilai-nilai moral dan kebenaran. Selain itu, siapapun yang melakukan perbuatan tidak baik dan tidak bermoral akan mendapatkan hukuman yang setimpal. Dalam film ini, Bangau mati tercekik oleh Kepiting di akhir cerita, karena perbuatan tak bermoralnya. Bangau mendapatkan hasil dari perbuatannya saat ini, dan habis dinikmati saat ini juga. Hukum tersebut pada norma agama Hindu dikenal dengan hukum Prarabda Karmaphala, yang merupakan salah satu dari tiga ajaran Karmaphala.

Perkembangan era digital dan teknologi saat ini dapat memungkinkan film animasi sebagai media dalam menyampaikan nilai-nilai pendidikan karakter dan pendidikan moral. Pendidikan karakter dan pesan-pesan moral dalam film animasi Pendeta Bangau dapat disampaikan secara menarik dan efektif melalui media audio dan visual yang ada. Adapun karakter-karakter dalam film animasi Pendeta Bangau dapat menjadi acuan tentang karakter mana yang patut dijadikan panutan dan yang tidak berdasarkan perbuatannya. Dalam film animasi ini, karakter Kepiting patut dijadikan panutan karena memiliki sifat yang jujur, sedangkan karakter Bangau tidak patut dijadikan panutan karena sifatsifatnya yang buruk seperti tidak jujur, serakah, selalu mengutamakan keuntungan pribadi, dan tidak bermoral.

Film animasi 2D Pendeta Bangau merupakan film animasi yang sangat menarik dan mengandung nilai-nilai pendidikan karakter dan moral yang baik dan penting untuk perkembangan anak sebagai generasi penerus bangsa. Sangat banyak cerita-cerita rakyat lainnya yang mengandung nilai pendidikan karakter maupun pesan moral, sehingga diharapkan analisis film animasi ini dapat menjadi referensi dalam menggali cerita-cerita rakyat lainnya yang berkearifan budaya lokal, khususnya cerita rakyat yang berbasis film animasi.

\section{DAFTAR ACUAN}

Balipost.com. 2017. "Selama Tahun 2017, 253 Anak Terlibat Kasus Hukum dan 10 Bayi Dibuang." 2017. http://www.balipost.com/news/2017 /12/21/32212/Selama-Tahun2017,253-Anak...html.

2019. "Dua Remaja Mencuri Emas dan Uang Dibekuk Polisi." 2019. 


\section{CAPTURE}

http://www.balipost.com/news/2019 /04/11/72733/Dua-RemajaMencuri-Emas-dan...html.

Bustaman, Burmansyah. 2001. Web Design Dengan Macromedia Flash Mx 2004. Yogyakarta: Andi Offset.

Danandjaja, James. 1991. Folklor Indonesia: IImu Gosip, Dongeng, Dan Lain-Lain. Jakarta: PT Temprint.

Gunawan, Bambang Bambi. 2013. Nganimasi Bersama Mas Be. Jakarta: Elex Media Komputindo.

Iskak, A. Yustinah. 2006. Apresiasi Film dan Drama. Jakarta: Erlangga.

Netra, Anak Agung Gde Oka. 2009. Tuntunan Dasar Agama Hindu. Denpasar: Widya Dharma.

Nuryantiningsih, Wiekandini Dyah Pandanwangi; Farida. 2017. "Animasi Kartun Bertema Falsafah Jawa sebagai Pendidikan Karakter Bagi Anak Usia Dini." Rekam 13 (1): 21-18.

Parmini, NI Putu. 2015. "Eksistensi Cerita Rakyat dalam Pendidikan Karakter Siswa SD di Ubud." Jurnal Kajian Bali 05 (02): 441-60. http://ojs.unud.ac.id/index.php/kajia nbali/article/download/16784/1105.

Prakosa, Gatot. 2010. Animasi Pengetahuan Dasar Film Animasi Indonesia. Jakarta: Fakultas Film dan Televisi Institut Kesenian Jakarta.

Pratista, Himawan. 2008. Memahami Film. Yogyakarta: Homerian Pustaka.

Rusman. 2017. Belajar dan Pembelajaran: Berorientasi Standar Proses Pendidikan. Jakarta: Kencana.

Sugiyono. 2015. Metode Penelitian Kuantitatif Kualitatif dan $R \& D$. Bandung: Alfabeta.

Trianton, Teguh. 2013. Film Sebagai Media Belajar. Yogyakarta: Graha IImu.

Wiguna, I. Made Arsa. 2015. "Mengurai
Nilai-Nilai Moral dalam Satuan sebagai Media Pendidikan Karakter di Era Global.” Prosiding Seminar Nasional Kearifan Lokal Indonesia Untuk Pembangunan Karakter Universal, 232-41.

Zaharuddin G. 2006. The Making of 3D Animation Movie Using 3DStudio Max. Bandung: Informatika.

Zembry. 2001. Animasi Web dengan Macromedia Flash 8. Jakarta: Elex Media Komputindo.

Zubaedi. 2011. Desain Pendidikan Karakter. Jakarta: Prenadamedia Group. 